\title{
"Truly, Much Can Be Done!": Cooperative Economics from the Book of Acts to Pope Francis
}

\author{
Nathan Schneider \\ University of Colorado Boulder
}

PREPRINT

for Care for the World: Laudato Si' and Catholic Social Thought in an Era of Climate Crisis, edited by Frank Pasquale (Cambridge University Press, $2019)^{1}$

At several key moments in Laudato Si, Pope Francis makes passing reference to cooperative economics - when speaking of a more human relationship with technology, for instance, and in relation to sustainable energy production. Reading these in light of his past statements on economic cooperation, it is evident that "cooperative," for him, is no vague nicety; rather, he is referring to a robust tradition of Catholic economic thought grounded in distributed ownership of the means of production and the precedence of persons over capital. This essay reviews the contours of the tradition that the pope is referring to, beginning with his own past statements on cooperative enterprise. It considers the foundations in biblical narratives of the early church; notions of the commons in early canon law; economic practices in monastic cultures; Catholic leadership in the emergence of modern cooperation; and the current, complex interactions between Catholic thought and the secular resurgence of cooperative economics. In addition to tying together historical threads, it draws from reporting on contemporary cooperative enterprise and on Francis's pre-papal history with cooperativism in Argentina. Cooperative

\footnotetext{
${ }^{1}$ This essay considerably expands on an earlier publication of mine, "How Pope Francis Is Reviving Radical Catholic Economics," The Nation (September 9, 2015). It has benefitted from feedback by Tim Huegerich, Mac Johnson, and Frank Pasquale.
} 
economics is a central yet under-appreciated backdrop to what the pope attempted to accomplish in Laudato $S i$, and a vital component of the hope for "integral ecology" that he envisions.

Among the controversies that accompanied the release of Pope Francis's Laudato $S i$ ' was a perplexing diversity of perceptions regarding the encyclical's mood. This wasn't so much a topic of outright dispute as it was a diversity of assumptions beneath the various salvos of analysis. ${ }^{2}$ Some readers experienced the text as in keeping with Francis's spirit of "the joy of the Gospel" articulated in his 2013 document Evangelii Gaudium. "Laudato Si" indeed!" proclaimed Michael Sean Winters in the National Catholic Reporter. "Our Holy Father has blessed the Church with a document that is accessible to virtually anyone, rich in the collected wisdom of the Catholic faith." ${ }^{3}$ Among the staff and fellow travelers of First Things, meanwhile, the timbre was quite different. Editor R. R. Reno's headline referred to its "weakness"; Deputy Editor Matthew Schmitz opined in The Washington Post on the pope's "dark tone"; New York Times columnist Ross Douthat characterized the text as "sprawling," "apocalyptic," and "foreboding."4

This latter interpretation was, for me, baffling. The encyclical's title translates as "praise be to you" - a quotation from a poem that revels in God's creation. Throughout, alongside the warnings and soundings of alarm, there are signs of progress, of possibility. Francis then concludes with a prayer that is nothing if not an exhortation to hope:

O Lord, seize us with your power and light, help us to protect all life, to prepare for a better future, for the coming of your Kingdom of justice, peace, love and beauty. (LS 294)

After puzzling over this difference of perception for a little while, I came to a theory that might, at least in part, account for it. (I would prefer to think

\footnotetext{
${ }^{2}$ I attempted to put the question of mood out into the open with "The Mood of 'Laudato Si": A Reply," America (June 22, 2015), which in turn garnered a response by Matthew Schmitz: "How 'Laudato Si" Praises God - and Smashes False Idols," America (June 23, 2015).

${ }^{3}$ Michael Sean Winters, "Laudato Si' Arrives," National Catholic Reporter (June 18, 2015).

${ }^{4}$ R. R. Reno, "The Weakness of Laudato Si," First Things (July 1, 2015); Matthew Schmitz, "Pope Francis Wants to Roll Back Progress. Is the World Ready?" The Washington Post (June 18, 2015); Ross Douthat, "Pope Francis' Call to Action Goes Beyond the Environment," The New York Times (June 20, 2015).
} 
that the matter can't merely be chalked up to self-described conservatives trying to undermine the message of a pope they perceive as liberal.) Perhaps, I surmised, the signs of progress and possibility that Francis cites aren't universally hopeful because they're not universally familiar. Perhaps some of us aren't clear on what he is talking about, on the reasons for the hope within him, on the long tradition of Catholic thought and practice to which he seems so joyfully to refer.

Consider, for instance, this passage, found in the last third of the encyclical:

There are no uniform recipes, because each country or region has its own problems and limitations. It is also true that political realism may call for transitional measures and technologies, so long as these are accompanied by the gradual framing and acceptance of binding commitments. At the same time, on the national and local levels, much still needs to be done, such as promoting ways of conserving energy. These would include favouring forms of industrial production with maximum energy efficiency and diminished use of raw materials, removing from the market products which are less energy efficient or more polluting, improving transport systems, and encouraging the construction and repair of buildings aimed at reducing their energy consumption and levels of pollution. Political activity on the local level could also be directed to modifying consumption, developing an economy of waste disposal and recycling, protecting certain species and planning a diversified agriculture and the rotation of crops. Agriculture in poorer regions can be improved through investment in rural infrastructures, a better organization of local or national markets, systems of irrigation, and the development of techniques of sustainable agriculture. New forms of cooperation and community organization can be encouraged in order to defend the interests of small producers and preserve local ecosystems from destruction. Truly, much can be done! ${ }^{5}$

It would require a bold feat of interpretation to understand "Truly, much can be done!" as apocalyptic or foreboding. But what is the cause of the pope's enthusiasm? Possibilities. He revels in a multifarious toolkit for the adventure of social and ecological reform. And the direct antecedent to his final exclamation - "new forms of cooperation and community organization" - seems to summarize the long litany and punctuate it. As popes often do,

${ }^{5}$ Ibid., $\$ 180$. 
when speaking of something new he is also speaking of something old; its simultaneous oldness and newness warrants the confidence of Francis's hope.

This essay will consider in depth what the encyclical means by "cooperation" as a form of "organization." This is not merely a vague invitation to collaborate and play nice. Additional references to cooperative organizing in the text, together with related statements elsewhere, make clear that Francis is referring to a specific kind of strategy that he considers to have special promise for social and ecological justice. Cooperation is not the only strategy he recommends, as this lengthy litany makes clear. Yet it is an important one, and has been almost universally ignored in the scholarly and journalistic commentary on Laudato Si'.

Economic cooperation ${ }^{6}$ is a way of doing business based in democratic ownership and governance among those the business most directly affects. Modern co-ops, unlike investor-owned corporations, generally commit to one-member-one-vote decision-making, rather than allocating more power to those who own more shares, and they aspire to cooperation among enterprises rather than competition. Such enterprises can take various legal forms, but they share an ownership model designed to maximize community benefit, not investor profits. ${ }^{7}$ Farmers' cooperatives have proven a dominant model for small-scale agricultural producers the world over, and credit unions consistently provide capital access in communities that investor-owned banks fail to serve. A 2014 United Nations report counted 2.6 million cooperatives, with over 1 billion memberships and more than 12.6 million employees internationally. ${ }^{8}$

This tradition of thought and practice has a long history and deep roots in Christian faith - Catholic tradition in particular. It's a legacy with which Francis has exhibited a robust familiarity. US Catholics by and large, however, seem to know little about cooperative economics or its relationship with their faith, even while church organizations continue to be among its chief supporters.

\footnotetext{
${ }^{6}$ I use terms like "cooperation," "cooperativism," "cooperative enterprise" to refer to the same phenomenon, though each carries a somewhat different emphasis.

${ }^{7}$ See the seven principles presently held in the global cooperative movement at "Co-operative Identity, Values \& Principles," International Co-operative Alliance, http://ica.coop/en/whats-co-op/co-operative-identity-values-principles.

${ }^{8}$ Dave Grace and Associates, Measuring the Size and Scope of the Cooperative Economy: Results of the 2014 Global Census on Cooperatives (United Nations Secretariat Department of Economic and Social Affairs Division for Social Policy and Development, 2014).
} 
Cooperativism is, on the one hand, a necessary key for interpreting Laudato $S i$, which explicitly recommends cooperative enterprise three times and repeatedly uses cooperation to describe the proper human posture toward God and creation; it is also a persistent, under-recognized theme in Francis's worldview and that of Catholic social thought for more than a century. For Francis, this kind of enterprise manifests the joy of the Gospel and proves the reasonableness of his call for "integral ecology." In what follows, I set out to reintroduce cooperative economics through the eye of Catholic tradition and Francis's own utterances.

\section{Francis (and Bergoglio) on Cooperative Economics}

Jorge Bergoglio was already a cardinal during Argentina's economic collapse in 2001. Among other improvisations during the crisis, workers in shuttered factories occupied them and kept them running under worker control; Bergoglio defended the popular uprisings during that time against police repression. ${ }^{9}$ He later acted as an advocate for an anti-trafficking organization called La Alameda, which emerged from a textile workers' cooperative and supported people escaping sweatshops and brothels, in part, by helping them form cooperative businesses. ${ }^{10}$

I spoke by phone with Néstor Escudero, ${ }^{11}$ a member of La Alameda, who described how Bergoglio would lend his visibility to protect the organization and those it served from retribution. This was, Escudero believes, an act of mercy on behalf of the vulnerable more than a means of favoring one business model over another. But the cardinal appreciated the business model as well. "We know that he supports co-ops because he has expressed it in meetings with other organizations when we had social movement gatherings," Escudero told me. Escudero also noted that there are reasons to be skeptical; co-op law in Argentina can sometimes become a means of skirting labor law and treating workers unfairly.

Bergoglio's positive perception of cooperative enterprise, however, was already well-rooted. In 2013, as Pope Francis, he responded with satisfaction to reports of co-ops that had managed to maintain their level of employment even during the recent financial crisis. This inclined him to tell a story

\footnotetext{
${ }^{9}$ Austen Ivereigh, "Gaucho Cardinal," in The Great Reformer: Francis and the Making of a Radical Pope (Henry Holt, 2014).

${ }^{10}$ Ivereigh, "Man for Others," in The Great Reformer.

${ }^{11}$ On June 19, 2015, with translation assistance from Caracol Interpreters Cooperative.
} 
he dated to 1954 , when he was still a teenager. "I heard my father" - an accountant - "speak on Christian cooperativism and from that moment I developed an enthusiasm for it, I saw that it was the way," Francis recalled. He went on:

It is precisely the road to equality, not to homogenity [sic], but to equality in difference. Even economically it goes slowly. I remember that reflection my father gave: it goes forward slowly, but it is sure. ${ }^{12}$

Two years later, Francis echoed this sentiment at the World Meeting of Popular Movements in Bolivia:

I have seen at first hand a variety of experiences where workers united in cooperatives and other forms of community organization were able to create work where there were only crumbs of an idolatrous economy. Recuperated businesses, local fairs and cooperatives of paper collectors are examples of that popular economy which is born of exclusion and which, slowly, patiently and resolutely adopts solidary [sic] forms which dignify it. ${ }^{13}$

The theme of gradual processes has been a persistent preoccupation for Francis. In Evangelii Gaudium he articulates four principles that have guided his ecclesiastical life over the years. The first of these, "time is greater than space," has been a motto for him at least since $1974 .{ }^{14}$ This might sound like an esoteric interpretation of physics, but the pope's explanation in Evangelii Gaudium is squarely about politics. "Giving priority to time," he writes, "means being concerned about initiating processes rather than possessing spaces."

Although a leader might be tempted to assert her power in the short term to score a victory, this motto insists that fostering healthy process matters more in the long run. It's a principle the pope put on display during the Synod on the Family proceedings in 2014 and 2015, before which he encouraged bishops to carry out consultations with the faithful. He then called the bishops to Rome for unusually transparent deliberations, to which his final conclusions deferred. Perhaps it would have been more expedient for him to simply

\footnotetext{
${ }^{12}$ Pope Francis, "Video message for the Third Festival of the Social Doctrine," Vatican.va (November 21-24, 2013).

13 "Pope Francis: Speech at World Meeting of Popular Movements," Vatican Radio (July 10, 2015).

${ }^{14}$ Ivereigh, "A Bishop Who Smelled of Sheep (1993-2000)," in The Great Reformer; Pope Francis, Evangelii Gaudium (Libreria Editrice Vaticana, 2013).
} 
assert his position and demand allegiance, but, seeking to inculcate habits of collegiality, he chose to institute a patient and participatory process.

Francis has also demonstrated awareness of the pitfalls that cooperative enterprises can face. In his 2015 address to the Confederation of Italian Cooperatives, he offered a warning:

When money becomes an idol, it commands the choices of man. And then it destroys man and condemns him. It renders him a servant. Money at the service of life can be managed in a just way by a cooperative, if however, it is an authentic, true cooperative, where capital is not in command over men but men over capital. ${ }^{15}$

However abstract, this speaks to a very specific phenomenon among large, longstanding co-ops that over time shed their cooperative identity by operating like conventional capitalist firms. He denies such firms the easy satisfaction of claiming the cooperative label. In an address to the same body the following year, Francis further develops this distinction between the "true cooperative" and others: "Counter the false cooperatives," he said, "because cooperatives must promote an economy of honesty." 16 Here, the honesty he's talking about involves solidarity within ("Manage the cooperatives truly cooperatively - that is, involving all") and service to the common good ("Participate actively in globalization in order to integrate - in the world - development, justice, and peace"). These concerns highlight a persistent tension between the cooperative principles of "democratic member control" and "concern for community." 17

While posing challenges such as these, Francis turns his hearers' attention to the past. As so often in Catholic discourse, tradition serves as a source of possibilities for the future. During the same 2013 address in which he recalled his father's endorsement of cooperation, Francis said:

I hope that all of you who are committed to cooperative reform, will keep alive the memory of their origins. The cooperative forms established by Catholics such as the implementation of Rerum Novarum bear witness to the power of faith, which today as then

\footnotetext{
${ }^{15}$ Pope Francis, "Address of His Holiness Pope Francis to Representatives of the Confederation of Italian Cooperatives," Vatican.va (February 28, 2015). Emphasis in the Vatican transcript.

16 "Pope Francis Encourages Cooperatives to Build Solidarity," Vatican Radio (May 5, 2016).

${ }^{17}$ Again, see "Co-operative Identity, Values \& Principles," International Co-operative Alliance.
} 
is capable of inspiring concrete action to respond to the needs of our people.

The reference to Pope Leo XIII's 1891 encyclical serves as a placeholder and a reminder: We are not stuck with solely the resources of the present. It's an allusion to the long history of cooperative experience in Christian faith and Catholic cultures. To hear the resonance of Francis's enthusiasm for cooperative enterprise, this often-neglected history merits recapitulation, even if it must be rough, brief, and cherry-picked from a vast and diverse tradition irreducible to any one type of economic advice.

\section{"All Things in Common"}

The biblical narrative for the birth of the Christian church describes a social order that bears at least a family resemblance to cooperative economics. Twice in the Book of Acts's account of the days following Pentecost, we read about Jesus's followers pooling property. Here is the first time, in chapter two:

Awe came upon everyone, and many wonders and signs were done through the apostles. All who believed were together and had all things in common; they would sell their property and possessions and divide them among all according to each one's need. ${ }^{18}$

Echoes of this language reappear again in the fourth chapter, where, two verses after another experience of "signs and wonders," we read that "the community of believers was of one heart and mind, and no one claimed that any of his possessions was his own, but they had everything in common."19 The subsequent chapter then tells the story of Ananias and Sapphira, who die sudden deaths after attempting to withhold from the community part of their earnings from a sale of land. When their story ends, again, "Many signs and wonders were done among the people at the hands of the apostles." 20 Evidently there is a link between the experience of divine activity in the world and the sharing of property among members of the Christian community; dishonest dealing in this arrangement has dire consequences. The lesson of Ananias and Sapphira holds a place of honor at St. Peter's Basilica in Rome, where a depiction of it appears on the canvas over the Altar of the Lie.

\footnotetext{
${ }^{18}$ Acts 2:43-45. This and all subsequent biblical quotations are from the New American Bible, http://usccb.org/bible.

${ }^{19}$ Acts $4: 32$.

${ }^{20}$ Acts 5:12.
} 
A chapter later, the apostolic commune experiences more growing pains. The original apostles find the task of resource management beyond their ken, evidenced by a recognition that the needs of widows are being neglected. They ask the community to select a board of seven trusted representatives to carry out the distributions. ${ }^{21}$ Their cooperation, as in modern cooperatives of any significant scale, was not opposed to hierarchy - but the hierarchy is appropriate and accountable.

This feature of the Bible, like so many others, keeps coming back to haunt Christendom, despite its imperial pretensions. The economic spirit of Acts reappeared with the monastic movements that arose and flourished as Christianity took institutional form in the later centuries of the Roman Empire. Citing Acts, the early-fifth-century Rule of St. Augustine instructs monastics, "Call nothing your own, but let everything be yours in common." 22 About a century later, Benedict of Nursia went further in his rule, stipulating, "As often as anything important is to be done in the monastery, the abbot shall call the whole community together," discussing the matter with everyone before making a decision. ${ }^{23}$ Benedict's rule prescribes election of the abbot by the community and enjoins the community to support itself through shared businesses. Both rules emphasize obedience to the abbot or abbess over democratic deliberation. But they also enjoin an egalitarian spirit and a collaborative economy.

The pattern of consultative authority recurred again during the thirteenthcentury mendicant movement. Clare of Assisi, Francis of Assisi's friend and colleague, enshrined in her rule for Franciscan sisters a measure of counter-cultural self-governance. The draft of the rule that Pope Innocent IV proposed for her order stipulated that the sisters' elected abbess must gain the approval of the male friars' minister general, a provision Clare struck from the final version. She also added the practice of a weekly chapter meeting - which apparently the pope deemed unnecessary - in which the sisters gather to confess their offenses and discuss "the welfare and good of the monastery." She stressed the inclusion of all community members in this,

\footnotetext{
${ }^{21}$ Acts 6:1-6.

${ }^{22}$ Augustine of Hippo, The Rule of St. Augustine, trans. Robert Russell (Brothers of the Order of Hermits of Saint Augustine, 1976).

${ }^{23}$ Benedict of Nursia, RB 1980: The Rule of St. Benedict in English, trans. Timothy Fry (Liturgical Press, 1981), 25. The relevance of the Benedictine rule to modern cooperativism is the subject of Greg MacLeod, "The Monastic System as a Model for the Corporate Global System," Work as Key to the Social Question conference on social justice, Vatican City (September 12-15, 2001).
} 
noting, "the Lord often reveals what is best to the lesser [among us]."24

Meanwhile, in the secular economy, a parallel model of cooperative-like enterprise appeared with the rise of the guild system. Guilds often took explicitly Christian form, providing members coverage for religious expenses such as burial (as well as justifying the economic exclusion of Jews, women, and others whose participation might challenge the allegedly Christian power arrangements of the time). ${ }^{25}$ While the guilds were highly regimented organizations, like monasteries, and demanded far less wealth-sharing, they did serve as a means for workers to participate in co-managing their economic lives, and to do so through a shared commitment to Christian solidarity.

Obviously medieval society was far from the absolute communism of the post-Pentecost ekklesia. Church doctrine recognized this tension and sought to reconcile it. Gratian's twelfth-century Decretum, the compendium of canon law that steered governance in the church for 800 years, held that "all things are common to all men." By the lights of natural law, at least, private property is an aberration, though under the conditions of fallen human society, it's a necessary, temporary arrangement. ${ }^{26}$ This doctrine has come to be called, including in the current catechism, ${ }^{27}$ "the universal destination of goods." Thomas Aquinas affirmed it, stressing that "man ought to possess external things, not as his own, but as common, so that, to wit, he is ready to communicate them to others in their need." 28 While these commitments do not predetermine the ownership structure of businesses among Christians, they do seem to encourage practicing private property in a way that reflects its provisional quality and the communal reality beneath it. There were and are many ways of doing so; in the twelfth century, for instance, the (female) Beguines and (male) Beghards maintained private enterprise and property while sharing real estate.

As during the early monastic and mendicant movements, practices of shared

\footnotetext{
${ }^{24}$ Chapter four of the Rule of St. Clare, in Francis and Clare: The Complete Works, trans. R.J. Armstrong (Paulist Press, 1988), 215-216. Bracketed words in the original.

${ }^{25}$ Steven A. Epstein, Wage Labor and Guilds in Medieval Europe (University of North Carolina Press, 1995); Sheilagh Ogilvie, "The Economics of Guilds," Journal of Economic Perspectives 28, no. 4 (Fall 2014).

${ }^{26}$ Robert Harry Inglis Palgrave (ed.), Dictionary of Political Economy, volume one (Macmillan, 1915), 212.

${ }^{27}$ Catechism of the Catholic Church, 2nd ed., (Liberia Editrice Vaticana, 1993), part 3, section 2, chapter 2, article 7.I.

${ }^{28}$ Thomas Aquinas, "Is It Lawful for a Man to Possess Something as His Own?" in Summa Theologica, trans. Fathers of the English Dominican Province (New Advent, 2008 [1920]).
} 
ownership have tended to feature prominently whenever reformers seek to challenge the moral authority of the church of their day and return to the core of the Gospel as they understand it. This was no less the case during the Protestant Reformation. While the Reformation helped ensure the rise of individualist, capitalist ownership models it also occasioned rhetorical and institutional innovations oriented toward cooperative economics. ${ }^{29}$

What has come to be called the "Radical Reformation" offers plentiful examples. Luther's militant rival Thomas Müntzer is said to have confessed, under the torture that preceded his execution in 1525 , "omnia sunt communia," or "all things are common"; more peaceable Anabaptist groups, meanwhile, were more lasting in their efforts to practice that biblical principle in everyday life and business - down to the Mennonites, Amish, and Hutterites still active today. In the midst of the English Civil War, the Diggers, under the eloquent leadership of Gerrard Winstanley, set out to win (by practicing, on a small scale, before their defeat) a social order based on common ownership of land, against both the receding feudal order and the emerging capitalist one. ${ }^{30}$ The Calvinist variant of the communal impulse found expression among the Puritans who settled in New England; though their initial experiment in shared farmland and produce was short-lived, their legacy has lived on in the region's town meetings and the congregationalist governance structure that still holds sway in much of US Protestantism.

None of these examples, Catholic or Protestant, exactly correspond with cooperative enterprise in the modern sense, and in certain respects they expressly challenge cooperative principles - for instance, in monasteries, the preference for poverty over ownership and obedience over autonomy. Nevertheless, such precursors indicate that, when the highest authorities of the Catholic Church began to take an interest in cooperatives as a response to the crises of modernity, they acted in continuity with longstanding traditions that preceded them. And in Rerum Novarum, the 1891 encyclical to which Francis alluded, Leo XIII describes the challenge of industrial labor relations as a breach in that continuity; "the ancient workingmen's guilds were abolished in the last century," he worried, "and no other protective organization took their place." 31

\footnotetext{
${ }^{29}$ Cf., Max Weber, The Protestant Ethic and the Spirit of Capitalism, etc. A valuable, though more Protestant perspective, on this story of Christian cooperation can be found in Andrew McLeod, Holy Cooperation! Building Graceful Economies (Cascade Books, 2009).

${ }^{30}$ Gerrard Winstanley, A Common Treasury (Verso, 2011).

${ }^{31}$ Leo XIII, Rerum Novarum (Libreria Editrice Vaticana, 1891), §3.
} 


\section{Apostolic Voices}

Salinas de Guaranda, an Ecuadorian mountain village most of a day's drive from Quito, has become a minor destination. It's home to factories making noteworthy cheese, chocolate, and textiles, as well as a dairy and a hostel, so there is plenty for a visitor to do and buy. At least part of its appeal, too, is the fact that each of these enterprises is owned by and accountable to Salinas's residents, all through a bewildering organizational structure surrounding their credit union. The village has become an engine for development throughout the region, spurring offshoots and replicas. The weekly town meeting takes place in an upper room next to the church on the main square, under the concrete cross mounted on the hill above; the gathering doubles as a prayer meeting. The whole system, it turns out, arose in the 1970s from the instigation of an Italian priest. ${ }^{32}$

Salinas is in some respects an exception - to the usual economic hopelessness of remote mountain towns, to the usual craving for rescue by multinational corporations - and in some respects not. Go on enough tours of impressive coops, and the story of Catholic influence repeats itself. The first credit union in the United States, St. Mary's Bank, was born of a New Hampshire parish in 1908 with the help of Alphonse Desjardins, founder of what would become Quebec's vast credit-union federation. The largest worker cooperative on record is Basque Country's Mondragon Corporation, which employs over 70,000 people in high-tech industry, finance, and retail; it, too, began with an enterprising priest, much like the one in Salinas.

This pattern may be at least partly attributable to the prehistory already outlined. But a legacy of monasteries, guilds, and biblical passages also seems inadequate to explaining the leadership that Catholics have exercised in the specific domain of modern cooperative enterprise. For that, Francis's nod to Rerum Novarum is instructive.

Cooperative enterprise arose in tandem with the rise of the industrial capitalism, although the length and breadth of this history is rarely known or told, even among cooperators themselves. ${ }^{33}$ As capital-intensive industry engulfed small trades and crafts, workers repeatedly sought arrangements in which

\footnotetext{
${ }^{32}$ Andrea Gagliarducci, "The Man Who Put Laudato Si into Practice in Ecuador - 40 Years Ago," Catholic News Agency (July 8, 2015).

${ }^{33}$ There are many early U.S. examples, for instance, in John Curl, For All the People: Uncovering the Hidden History of Cooperation, Cooperative Movements, and Communalism in America, 2nd ed. (PM Press, 2012).
} 
they could retain ownership of the means of production and the revenue from their labor. Though its origins go back at least several decades earlier, and dispersed across many other countries, the modern cooperative movement is often traced to the 1844 founding agreements for a cooperative store in Rochdale, England, which would become an influential model elsewhere. These principles enshrined one-member-one-vote democracy, the distribution of surpluses to members, transparent accounting, and the promotion of education. Religious influences were certainly at work in Rochdale, but the orientation was ecumenical, not ecclesiastical; when the International Co-operative Alliance distilled the lessons of the Rochdale store in 1937, the first was "open membership" and the fifth was "political and religious neutrality." 34 To the Rochdale Society of Equitable Pioneers, as the store's founders called themselves, the ancient and hierarchical Catholic Church probably seemed remote from the new cooperative economic order they envisioned.

It was only later in the nineteenth century that the foundations began to form for a specifically Catholic cooperativism. When Leo XIII promulgated Rerum Novarum (or, Rights and Duties of Capital and Labor) in 1891, he appears to have understood his church as standing between a materialist-socialist rock and a robber-baron-capitalist hard place. Decades of revolution and class conflict had shaken Europe, cracking many of the church's familiar secular buttresses. He laments "the enormous fortunes of some few individuals, and the utter poverty of the masses" that industrial capitalism had brought about, but he cannot accept the socialists' alternative, which would "rob the lawful possessor, distort the functions of the State, and create utter confusion in the community." 35 His third-way solution, rather than accumulating power in either capital or the state, is to double down on private property and provide for its more widespread distribution: "The law, therefore, should favor ownership, and its policy should be to induce as many as possible of the people to become owners." 36

To accomplish this, Leo affirms the need for Christian workers' organizations to demand fair wages and facilitate mutual aid. But this should take harmonious, Christian form, eschewing acrimonious strikes and riots, for "capital cannot do without labor, nor labor without capital." 37 Even while asserting

\footnotetext{
${ }^{34}$ The Present Application of the Rochdale Principles (International Co-operative Alliance, 1964).

${ }^{35}$ Leo XIII, Rerum Novarum, $\$ 1$ and $\S 4$.

${ }^{36}$ Ibid., $\$ 46$.

${ }^{37}$ Ibid., $\$ 19$.
} 
the priority of property, he retains the spirit of the universal destination of goods, by which property should be used in the service of the commonweal. The encyclical doesn't include an explicit embrace of Rochdale-style cooperation, while nevertheless providing the basis for its subsequent adoption pointing away from state socialism and toward forms of economic life that enable more collaborative labor relations. The solution Leo offers workers is not to expropriate the means of production and deliver them to a high and mighty state, but to seek more equitable ownership for themselves.

Exactly forty years later, in the 1931 encyclical Quadragesimo Anno, Pope Pius XI heralds at length the reception history of Rerum Novarum: "The Apostolic voice did not thunder forth in vain," he boasts. ${ }^{38}$ He speaks of the various labor organizations and study circles and other communal experiments that emerged from his predecessor's provocation. Even as the Great Depression swelled to full force, his tone is of momentum and optimism.

In England, Leo XIII's outline for more widely distributed ownership had begun to crystallize into a sui generis political philosophy. Cardinal Henry Manning of Westminster, one of the major contributors to Rerum Novarum, had a young acolyte in Hillaire Belloc, whose mother's conversion to Catholicism Manning had guided. Belloc became a public intellectual in his own right, and much of his career could be summarized as an attempt to interpret and defend the vision of Rerum Novarum. In the process he introduced the encyclical and its implications to Cecil and Gilbert Chesterton, which aided in converting the brothers to Catholicism and away from statist socialism. The three called their synthesis "distributism." Together, in bellicose polemics and debates, they described a distributist system of family businesses and parish associations, although they could rarely satisfy questions of how to get there. They also had a tendency to level accusations at high finance in anti-Jewish terms and cheer along the ascendent fascists. From time to time, they mentioned cooperatives. ${ }^{39}$

Pius XI, in Quadragesimo Anno, also sought to further and systematize what Rerum Novarum began. He put a name to the logic of subsidiarity that animates Rerum Novarum, the principle that governance should remain as local as possible. Although affirming the basic justice of wage-based

\footnotetext{
${ }^{38}$ Pius XI, Quadragesimo Anno (Libreria Editrice Vaticana, 1931), §12.

${ }^{39}$ For this account and much else, I am indebted to Race Mathews, Jobs of Our Own: Building a Stakeholder Society: Alternatives to the Market and the State (Pluto Press, 2009) and Jay P. Corrin, Catholic Intellectuals and the Challenge of Democracy (University of Notre Dame Press, 2002).
} 
employment, he gestures toward the kind of shared equity that is so central to cooperative enterprise, recommending that

the work-contract be somewhat modified by a partnershipcontract, as is already being done in various ways and with no small advantage to workers and owners. Workers and other employees thus become sharers in ownership or management or participate in some fashion in the profits received. ${ }^{40}$

The encyclical was drafted chiefly by a German Jesuit who later stated his intent as "progressive, liberal, definitely democratic, against individualism and against statism," but the final text and its reception turned out to be more ideologically ambiguous. ${ }^{41}$ Late in the drafting process, Pius XI added a passage that addressed, though not by name, the fascist system then emerging under Benito Mussolini in Italy: a tripartist collaboration among capital, labor, and the state. He approved of how such a system could align competing interests of industry toward the common good. But the pope's comments expressed concern that the state was overreaching its bounds and dominating the other parties; "instead of confining itself as it ought to the furnishing of necessary and adequate assistance," he worried, the regime "is substituting itself for free activity." 42 He recommended, as an antidote, the kinds of lay Catholic Action organizations that were then developing cooperatives, among other things, and which Mussolini had been suppressing. Mussolini complained about these comments; Pius XI claimed they were merely a "benevolent nod." Many since have read the encyclical's critique as dangerously close to an endorsement.

Between Pius XI's prewar involvements with Catholic dictators and the English distributists' racist fits, the ideological foundations of Catholic cooperativism make for a checkered pedigree. What's more, the doctrines of neither the popes nor the distributists provided a thorough blueprint for the harmonious society of equitable ownership and subsidiaristic governance to which the authors aspired. It was in places like Salinas, in the field of practice, that distinctly Catholic and remarkably effective approaches to cooperative enterprise would take shape.

\footnotetext{
${ }^{40}$ Pius XI, Quadragesimo Anno, $\$ 65$.

${ }^{41}$ Oswald von Nell-Bruening, "Documentation: The Drafting of Quadragesimo Anno," Crisis Magazine (February 1, 1985); Paul Misner, "Catholic Labor and Catholic Action: The Italian Context of Quadragesimo Anno," The Catholic Historical Review 90, no. 4 (October 2004).

${ }^{42}$ Pius XI, Quadragesimo Anno, §95.
} 


\section{Cooperation through Formation}

After an event at which I spoke in Melbourne, Australia, in mid-2016, a young cooperator then working for the local archdiocese introduced me to an elderly man who'd been in the audience. ${ }^{43}$ The man had something he wanted to say. He came close to me and began to speak, from which I recollect only one crucial word: formation.

The man's name was Race Mathews. And despite his reference to a theological concept, he confessed to being neither a Catholic nor a believer. For most of his career, before retiring to study the prehistory of the modern cooperative tradition, he was a politician and official in Australia's Labor Party. The importance of formation was his latest discovery.

Formation is a word now used frequently in Catholic discourse, though its distinct Catholic usage is rarely defined outright. It refers to a Christian's ongoing conversion to Christianity - through prayer, study, and experience. The kind of formation one receives depends on one's outside influences and one's interior choices, and it molds what kind of Christian one becomes. Economic life is part of a person's formation, too.

Since the 1980s Mathews has made a series of visits to the Mondragon Corporation. This remarkable network of worker co-ops emerged under the shadow of Franco in the 1950s through the guidance of a local priest, José María Arizmendiarrieta - Arizmendi for short. It's a system of factories, schools, banks, retailers, and more, all owned and governed by people who work in them. It's a beacon of possibility, the world over, that democratic business can work at large scale, though it has yet to be outdone or replicated.

Mathews' 2009 book Jobs of Our Own traces Arizmendi's precursors, including Rerum Novarum and the British distributists. In Mondragon, Mathews saw a practical manifestation of the ideas earlier Catholics had only alluded to, dubbing it "evolved distributism." But only after publishing the book, while studying the Catholic Action and Young Christian Workers movements that influenced Arizmendi, did Mathews zero in on the concept of formation.

Mondragon, he realized, is a monument not only to a particular way of doing business but to a vision for forming the souls who partake in it. Before Mondragon opened for business in 1956, Arizmendi started a school where he and his students developed their plans together over the course of a decade.

\footnotetext{
${ }^{43}$ Some readers may recognize passages here adapted from my article "A New Way to Work," America (August 15-22, 2016).
} 
They let diverse influences form them, religious and otherwise. Following the teachings of Young Christian Workers founder Cardinal Joseph Cardijn teachings that also influenced Jorge Bergoglio - they practiced the method of "see, judge, act." They tested their ideas relentlessly and creatively through practice, and then adjusted those ideas accordingly. "Hand in hand, of one mind, renewed, united in work, through work, in our small land we shall create a more human environment for everyone," Arizmendi wrote just days before his death in 1976. "Everyone shall simply work for the benefit of everyone else, and we shall have to behave differently in the way we work." 44

The centrality of education for Mondragon is hard to overstate. "It has been said that cooperativism is an economic movement that uses the methods of education," Arizmendi once wrote. "This definition can also be modified to affirm that cooperativism is an educational movement that uses the methods of economics." 45 The reasons for Mondragon's success are complex enough to be infinitely open to interpretation, but among them is surely the view of participants' spiritual development as an end in itself, rather than simply a means toward enacting an abstract economic system.

This emphasis points to a further, vital influence for Arizmendi and his followers, alongside Rerum Novarum economics. The priest's teachings frequently echoed the philosophy of personalism articulated by Catholic thinkers like Jacques Maritain and Emmanuel Mounier, in which recognizing and cultivating the God-bestowed dignity of human persons constitutes the heart of the Gospel. Formation, in this light, is no rote indoctrination; it is an invitation to divine freedom and flourishing.

Arizmendi's personalism also did much to escape the reactionary tendencies of earlier, more theoretical Catholic cooperativism. He taught, at least later in life, a commitment to gender equality. "To advance in life without the collaboration of women," he wrote, "is to attempt to run with only one foot." 46 And emerging as Mondragon did in quiet defiance of the Franco regime's repressions of the Basques, it belied its predecessors' fascist flirtations.

While Mondragon was uniquely successful, this cooperative expression of Catholic social teaching was far from unique. Across the Atlantic, a separate but very much parallel manifestation of Catholic cooperativism appeared.

\footnotetext{
${ }^{44}$ Quoted in Race Mathews, Manning's Children: Responses to Rerum Novarum in Victoria, 1891 to 1966, MCD University of Divinity thesis (March 2014), 94-95.

${ }^{45}$ José María Arizmendiarrieta, Reflections (Otalora, 2013), §213.

${ }^{46}$ Arizmendiarrieta, Reflections, §73.
} 
Antigonish, Nova Scotia, like Mondragón, was an impoverished place far from the capitals of culture and industry - at the "periphery," to use a favorite word of Pope Francis's. And again, what would become the Antigonish movement began with a priest and a school. Fr. Jimmy Tompkins, and then Fr. Moses Coady, starting in the mid-1920s, used a Jesuit university's extension program as a vehicle for reaching working people with cooperative ideas and study groups, learning together about the Desjardins credit union in Quebec and the Rochdale model. With the onset of the Great Depression, the study turned into organizing. By 1932, they'd set up around 200 local organizations with around 10,000 members. This spurred a flourishing of co-ops, credit unions, and study groups throughout the region. ${ }^{47}$

As Arizmendi would in decades to come, Tompkins and Coates brought the spirit of Rerum Novarum into a patient, practical process of education and formation. Alongside encyclicals, they drew freely from secular experiments and the know-how of the people they worked with. The Antigonish movement gained enough international visibility by 1938 to merit a letter from the Vatican under Pius XI, signed by Cardinal Eugenio Pacelli, who would become Pope Pius XII the following year; "May the work grow and flourish," it said. ${ }^{48}$ The late 1930s, as it happened, would mark the movement's peak, but the Antigonish model would help spur a broader Catholic cooperative movement that would continue to mature and proliferate.

One can try one's best to assemble a litany of Catholic cooperative efforts during the past century, but in the process one becomes all the more aware of coming up short. The Confederation of Italian Cooperatives, founded in 1919, led to a flourishing of specifically Catholic co-ops throughout the country, alongside those associated with liberals and communists. In the Southern United States, the African-American Spiritan priest Fr. Albert J. McKnight became one of the architects of a cooperative system that enabled thousands of black farmers to keep their land and make a living - despite a racist social order, which their co-ops would help them to resist in the Civil Rights movement. President Jimmy Carter appointed McKnight to the founding board of the National Cooperative Bank in 1979. Meanwhile in New York, the lay-edited magazine Jubilee, active between 1953 and 1967, organized itself as a consumer cooperative, with shares owned by subscribers; this model took inspiration from journalist and children's book

\footnotetext{
${ }^{47}$ Chapters 7 and 8 of Mathews, Jobs of Our Own; Jacob Remes, "In Search of "Saner Minds': Bishop James Morrison and the Origins of the Antigonish Movement," Acadiensis 39, no. 1 (Winter/Spring 2010): 58-82.

${ }^{48}$ Mathews, Jobs of Our Own, 153.
} 
author Clare Hutchet Bishop's All Things in Common, a lyrical dispatch from among the cooperative industries that appeared throughout France after World War II. Around the world, Catholic mission agencies have supported cooperatives among poor farmers and craftspeople, which enable them to bring their products into the global market without relying on multinational corporations. Catholic Relief Services calls this kind of methodology "integral human development." 49

All along, the pedagogical aspect of cooperation - the potential for certain kinds of formation - has been of particular interest to Catholics. This benefit was evident enough by 1916, for instance, that the prominent US Catholic economist Monsignor John A. Ryan devoted a chapter to co-ops in his book Distributive Justice. In addition to concluding that cooperation "always makes directly for a better distribution of wealth," he writes:

Co-operation has, in the second place, a very great educational value. It enables and induces the weaker members of economic society to combine and utilise energies and resources that would otherwise remain unused and undeveloped; and it greatly stimulates and fosters initiative, self confidence, self restraint, self government, and the capacity for democracy. In other words, it vastly increases the development and efficiency of the individual. ... Its fundamental and perhaps chief merit is that it does provide the mechanism and the atmosphere for a greater development of the altruistic spirit than is possible under any other economic system that has ever been tried or devised. ${ }^{50}$

Ryan's ideas would go on to influence the shape of the New Deal, whose programs led to a massive expansion of agricultural and electric-utility co-ops across the United States. In 1919 he also drafted the US bishops' Program of Social Reconstruction, which regards wage-based employment as inadequate and commends cooperative ownership models instead; the bishops' landmark 1986 statement Economic Justice for All quotes from those remarks before

\footnotetext{
49"Father Albert McKnight," Cooperative Hall of Fame, http://heroes.coop/archive/father-albert-mcknight; Albert J. McKnight, Whistling in the Wind: The Autobiography of Fr. Albert J. McKnight (Southern Development Foundation, 2011); Mary Anne Rivera, "Jubilee: A Magazine of the Church and Her People: Toward a Vatican II Ecclesiology," Logos: A Journal of Catholic Thought and Culture 10, no. 4 (Fall 2007); Catholic Relief Services, "Agency Strategy," http://agency-strategy.crs.org.

${ }^{50}$ John A. Ryan, "Co-Operation as a Partial Solvent of Capitalism," in Distributive Justice: The Right and Wrong of Our Present Distribution of Wealth (Macmillan, 1916).
} 
encouraging experimentation in cooperative enterprise, citing Mondragon. ${ }^{51}$

While many of the most full-throated co-op advocates nowadays are selfdescribed progressives, cooperativism and related discourses continue to cross left-right political lines much as they did a century ago among the British distributists. Legislators representing conservative rural districts are among the first to champion electric co-ops and credit unions. Catholics have been notably vocal. Both Republican Jeb Bush and Democrat Tim Kaine, for instance, have advocated easing financial regulations on credit unions and community banks; Republican congressman Paul Ryan has flummoxed progressive Catholics by defending his proposals for welfare reform with the language of subsidiarity.

In my reporting on the young people who are transforming the cooperative movement today, I frequently encounter non-Catholic cooperators who take it for granted - without necessarily knowing why - that Catholic organizations have been steady and quiet supporters of co-ops. The US bishops' Catholic Campaign for Human Development, for instance, has invested in the fledgling US Federation of Worker Cooperatives, as well as Cooperation Texas, a regional co-op developer, and individual co-ops like Opportunity Threads, a worker cooperative "eco-textile" plant in North Carolina. ${ }^{52}$ Catholic Relief Services is an "interfaith partner" of Equal Exchange, a cooperative coffee company, encouraging parishes across the country to serve the company's fair-trade products. On a smaller scale, the Jesuit parish of St. Robert Bellarmine in Cincinnati, Ohio, helped open Community Blend, a workerowned cafe, in 2014. ${ }^{53}$ Cincinnati's Xavier University, to which the parish is connected, held a conference in April 2016 on "The Cooperative Economy: Building a Sustainable Future."

Many of these efforts take place without publicity, and often Catholics themselves aren't aware of the leadership role their co-religionists have taken and are taking in creating cooperative economic alternatives. One Jesuit professor, the assistant to the University of San Francisco's president, lamented in 2000, "Considering the number of business schools and law schools

\footnotetext{
${ }^{51}$ Administrative Committee of the National Catholic War Council, Program of Social Reconstruction, 1919; United States Catholic Bishops. Economic Justice for All: Pastoral Letter on Catholic Social Teaching and the U.S. Economy. 1986.

${ }^{52}$ Joseph Purello, "Catholic Campaign for Human Development Funds Textile Cooperative in Morganton," Catholic News Herald (December 12, 2012).

53 "Catholic Relief Services Partnership," Equal Exchange, http://equalexchange.coop/catholic-relief-services; Nathan Schneider, "I Was Wrong About Catholic Co-ops," America (November 24, 2014).
} 
in U.S. Catholic universities, the lack of creative thinking on cooperatives is surprising." 54 Yet the practical achievements of Catholic cooperativism have secured the notice of popes, at least, on a regular basis.

"It is not possible to give a concise definition of the kind of economic structure which is most consonant with man's dignity and best calculated to develop in him a sense of responsibility," John XXIII's Mater et Magistra of 1961 admits. ${ }^{55}$ Yet the document commends Pius XII's encouragement of small producers banding together in cooperatives. Especially in agricultural life, it concludes, "We therefore desire here to express Our satisfaction with those sons of Ours the world over who are actively engaged in co-operatives." 56

A 1998 address to credit unionists by John Paul II began with some credittaking. "The institution you represent," he said, "draws its inspiration precisely from the Church's fruitful Magisterium and is one of its most significant concrete achievements." 57 He cited Rerum Novarum's influence in spurring the co-op movement and warned, "These values must be safeguarded in a 'market' that is always in danger of forgetting that" - here referencing his own encyclical Sollicitudo Rei Socialis, together with the ancient universal destination of goods - " "the goods of creation are meant for all." "

Benedict XVI also discerned agreeable resonance between the cooperative model and Catholic teaching. In his December 2011 address to the Confederation of Italian Cooperatives, he said of the model:

It is a practical expression of complementarity and subsidiarity which the Church's social doctrine has always encouraged between the person and the State; it is the balance between the safeguard of the rights of the individual and the promotion of the common good in the effort to develop a local economy that responds more and more to the needs of the group. ${ }^{58}$

He went on to encourage the Italian co-ops to keep Christian spirituality at the center of their work - living out an economy "of giving freely, of

\footnotetext{
${ }^{54}$ George E. Schultze, "Workplace Democracy as Church," Peace Review 12, no. 2 (2000): 235.

${ }^{55}$ John XXIII, Mater et Magistra (Libreria Editrice Vaticana, 1961), §84.

${ }^{56}$ Ibid., $\$ 148$.

${ }^{57}$ John Paul II, "Promote Real Economic Democracy," address to the Central Institute of Cooperative Credit Banks (June 26, 1998), http://cin.org/jp2/jp980626.html.

${ }^{58}$ Benedict XVI, "Address to Members of the Confederation of Italian Cooperatives and of the Italian Federation of Cooperative Credit Banks," Libreria Editrice Vaticana (December 10, 2011).
} 
responsibility, of promoting a responsible and moderate consumption."

The following year Benedict XVI shared a message to the United Nations on World Food Day, whose theme that year (as part of the UN International Year of the Cooperative) centered on agricultural cooperatives. Again he raised the theme of co-ops as a mechanism for forming participants in the "human, social, cultural and moral development" that the church seeks to engender; he also celebrated the leadership role women often take. "It is indispensable that national and international authorities provide the necessary legislation and financing" to support rural cooperation, he concluded.

One could go on. Suffice it to say that, by the second half of the twentieth century, popes had more to go on than Rerum Novarum's broad-stroke recommendations for more equitably distributed ownership. There was enough actually-existing Catholic cooperation to demonstrate the model's prowess both for establishing fair economic conditions and for forming the souls of participants in conformity with Catholic teaching. Already, too, Catholics had become leaders in the cooperative movement the world over, from famous cases-in-point like Mondragon to the countless, unsung co-ops that church relief organizations have supported in precarious communities.

Pope Francis's own plentiful statements about cooperative enterprise stand in continuity with those of his predecessors; their existence comes as no surprise. Yet Francis also demonstrates a special tenderness for cooperation, as well as an especially sophisticated understanding of its prospects and pitfalls. He wields the co-op alternative as part of his barbed critique of the capitalist order's "idolatrous economy," while encouraging cooperators to resist the temptation to compromise too much. Rather than uplifting co-ops only in a specific sector, he recognizes that they can take many forms, in many industries, and can serve as a means for addressing a variety of social ills. In particular, and particularly in Laudato $S i$, he identifies the resonance between cooperative enterprise and an aspect of the Christian calling that his predecessors didn't equally appreciate: stewardship of God's creation.

\section{"Social Worship"}

America magazine, the national Jesuit review, has a front-of-the-book section of short editorials opining on issues of the day. The October 21, 1944, issue includes one such entry entitled "Catholics and Cooperatives," alongside a call to "Recognize DeGaulle." It opens by paying tribute to "Iowa in 
October" - "a lovely country" of "rolling prairie" and "glowing colors" before turning to the human action. In the town of Westphalia, the unnamed author describes a parish community celebrating the Rochdale Centennial with apple picking, cow milking, and a solemn mass, all under the aegis of the Catholic Cooperative Committee, which supports the parish's several cooperatives. A bishop is quoted speaking approvingly. The author takes it for granted that this is but one place where similar scenes are playing out across the country, for the cooperative model "has long since passed the experimental stage." This is "a parish," we're told, "which draws the light and strength for its economic life from the Catholic ideal of truly social worship."

The ease and normalcy with which the editorial speaks of Catholic cooperation is no longer with many of us. In the years after World War II, the US cooperative movement fell victim to postwar prosperity and Red-baiting repression. Many of those cooperatives that have remained in force, particularly among farmers and rural utilities, have become rigid to the point that their members are not even aware of being members of a cooperative. Co-ops that do claim their identity with pride, meanwhile, often seem to serve marginal countercultures and thereby lack appeal for the mainstream. The everydayness of the editorial reminds us that this was not always the case.

At the same time, the "social worship" so eloquently named there prefigures a calling very much of our moment. In the juxtaposition between the natural world - that "lovely country" - and the harmonious economy operating therein, we should recognize an example of the "integral ecology" that Francis proposes in Laudato $S i$ '. Unlike the scientistic or animistic visions that have long motivated secular environmentalism, integral ecology aspires to a form of stewardship that integrates natural science, social justice, and authentic spirituality without sacrificing any of them to the others - "an approach to ecology," Francis writes, "which respects our unique place as human beings in this world and our relationship to our surroundings" (LS $15)$.

The encyclical's subtitle, On Care for Our Common Home, alludes to the universal destination of goods, which lends new meaning to Genesis in an age of planetary crisis. "All of us can cooperate as instruments of God for the care of creation," he writes; elsewhere, he speaks of a God "who wishes to work with us and who counts on our cooperation" (LS 14, 80). Francis challenges readers to establish an economic order that makes a priority of long-term 
sustainability rather than short-term extractive gain - an "economic ecology," as he puts it (LS 141). And there is every reason to surmise that cooperative enterprise is a sensible way to begin practicing this.

The pioneering work of political scientist (and Nobel laureate in economics) Elinor Ostrom suggests how forms of local self-governance and mutual investment have resulted in efficient, ecologically sustainable outcomes. ${ }^{59} \mathrm{In}$ countries like Germany and Denmark that have been leading the turn away from fossil fuels, cooperatives have been a formidable mechanism for financing and managing renewable energy systems; even in the United States, green-energy advocates see existing rural electric co-ops as potential leaders in the transition because they're more responsible to the holistic needs of communities they serve than to investors' cravings for short-term profits. ${ }^{60}$ Francis refers to such prospects in Laudato Si':

In some places, cooperatives are being developed to exploit renewable sources of energy which ensure local self-sufficiency and even the sale of surplus energy. This simple example shows that, while the existing world order proves powerless to assume its responsibilities, local individuals and groups can make a real difference. They are able to instill a greater sense of responsibility, a strong sense of community, a readiness to protect others, a spirit of creativity and a deep love for the land. They are also concerned about what they will eventually leave to their children and grandchildren. These values are deeply rooted in indigenous peoples (LS 179).

Here we see that Francis views local cooperation as a source of innovation, not just as a means of hearkening back to a slower, simpler existence. Earlier he writes, "We have the freedom needed to limit and direct technology" but this is not a call for mere retrenchment. "We can put it at the service of another type of progress," he goes on, "one which is healthier, more human, more social, more integral" (LS 112). That precedes the first of the encyclical's three explicit references to cooperative enterprise (though the last quoted here):

\footnotetext{
${ }^{59}$ Elinor Ostrom, "A General Framework for Analyzing Sustainability of Social-Ecological Systems," Science 325, no. 5939 (July 24, 2009).

${ }^{60}$ This is a challenge since most US electric co-ops are entangled in contracts that commit them to coal. Özgür Yildiz et al., "Renewable Energy Cooperatives as Gatekeepers or Facilitators? Recent Developments in Germany and a Multidisciplinary Research Agenda," Energy Research 85 Social Science 6 (March 2015); John Farrell et al., Re-Membering the Electric Cooperative (Institute for Local Self-Reliance, 2016).
} 
Liberation from the dominant technocratic paradigm does in fact happen sometimes, for example, when cooperatives of small producers adopt less polluting means of production, and opt for a non-consumerist model of life, recreation and community.

This is not liberation from technology as a whole, but from a paradigm in which the apparent needs of profit-oriented technology take precedence over social, spiritual, and ecological flourishing. Likewise, Fr. Arizmendi insisted that cooperatives must be technologically dynamic and well-capitalized enough to innovate; to this end, he founded Mondragon Corporation with students at a technical school, and ever since it has maintained units devoted to R\&D. He took the imperative of innovation for granted, though not as an end in itself. "Tools and machines need to be continuously renewed," Arizmendi wrote, "but above all there has to be a renewal in the mentality of human beings." 61

Francis regards cooperative enterprise as a proven method for putting economic activity under the control of stakeholders who have more at stake than investors playing with money; these are the workers, the customers, the producers, the neighbors, the people who drink the nearby water and breathe the same air. Cooperation is for him, therefore, a cause for hope. It is not the ultimate goal or a one-size-fits-all solution to everything; he points also to international agreements, policy tweaks, changes in personal habits, and more. But cooperation does provide a reason to believe that the ambition of integral ecology is not beyond reach. If one is familiar with the cooperative legacy, the encyclical's central doctrine is more likely to seem practically plausible and intellectually satisfying. If not, one may be more likely to view the doctrine as dark and foreboding - a lost cause, a charge toward collective martyrdom. But that is not the intent. Bound up in the call for integral ecology is a call for a cooperative revival.

To begin with, it is a call for those who claim allegience to Catholic faith and its social teaching to reacquaint themselves with the theory and practice of cooperative enterprise. In more than a decade since becoming a Catholic I have neither seen nor heard of an extant Catholic Cooperative Committee at a parish; I've never heard a priest recommend economic cooperation from the pulpit or a leading Catholic intellectual mention it in the mass media

\footnotetext{
${ }^{61}$ Arizmendiarrieta, Reflections, $\$ 180$. For a contemporary example of technologically oriented cooperativism, see Trebor Scholz and Nathan Schneider (eds.), Ours to Hack and to Own: The Rise of Platform Cooperativism, a New Vision for the Future of Work and a Fairer Internet (OR Books, 2016).
} 
- at least in the United States. When I sought to learn more about the backdrop of the encyclical, I encountered economists from the old Italian "civil economy" tradition like Stefano Zamagni and Leonardo Becchetti, who spoke to me of cooperatives as a natural feature of a healthy society. It's no accident that Zamagni has been an influential shaper of recent social encyclicals.

There are many opportunities for Catholics to reclaim their leadership role in the cooperative movement. Catholic schools and hospitals can act as "anchor institutions," using the money they expect to spend on essentials like food, laundry services, construction, and electricity to finance worker-owned green businesses. ${ }^{62}$ Parishes and dioceses can operate credit unions equipped to supplant abusive payday lenders and provide financing for rooftop solar panels. Networks of such cooperatives, connected through existing church institutions, can share local best practices globally and invest in technology that meets their needs more efficiently. Perhaps before all else, Catholic communities can form study groups to reflect on the economic formation at work in their lives and how they might align their economies more closely with an integral ecology. As Francis recommends at the outset of the encyclical, they can do these things with non-Catholic partners in pursuit of the common good.

For all the empowerment that economic democracy might offer, however, for Francis it renders no substitute for humility. "It is important that we not think of ourselves as self-sufficient," he has counseled elsewhere. ${ }^{63}$ The pope nevertheless allows himself to express hope in Laudato $S i$ ' for implementing integral ecology - with an exclamation mark, no less - in part because he knows the accomplishments of alternatives like the cooperative model, as well as his predecessors' role in helping to motivate it. If Rerum Novarum eventually led to Mondragon, perhaps Laudato Si' can inspire a green-energy revolution whose benefits accrue more widely, and more accountably, than those of the oil conglomerates. If workplaces operated more like a village dairy cooperative in the Andes, perhaps work would start to feel more like social worship. If an economy can regard its participants as co-creators, maybe they'll rediscover their role as stewards of creation. In the meantime, much can be done.

\footnotetext{
${ }^{62}$ See, published by the Democracy Collaborative, a leading advocate of the anchor institution model: The Democracy Collaborative, "Anchor Institutions," http://communitywealth.org/strategies/panel/anchors/index.html.

${ }^{63}$ Francis, The Name of God Is Mercy (Random House, 2016), 58.
} 